\title{
PELATIHAN DAN PENDAMPINGAN PENINGKATAN KEMAMPUAN SKRENING SINDROM METABOLIK DI DESA PA'LALAKANG KABUPATEN TAKALAR
}

\author{
Aminuddin Syam ${ }^{1 *}$, Nurhaedar Jafar ${ }^{1}$, Yessy Kurniati ${ }^{2}$, Devintha Virani ${ }^{1}$, Irma Adriani $^{3}$ \\ ${ }^{1}$ Program Studi IImu Gizi, Universitas Hasanuddin \\ 2 Program Studi Kesehatan Masyarakat, Universitas Islam Negeri Alauddin \\ ${ }^{3}$ Departemen Biologi, Universitas Hasanuddin \\ Jalan Perintis Kemerdekaan 10 Tamalanrea, Makassar, 90245 \\ ${ }^{*}$ Korespondensi: amin.giziuh@gmail.com
}

Diterima November 2019 / Disetujui 09 Januari 2020

\begin{abstract}
ABSTRAK
Sindroma metabolik adalah kondisi seseorang yang memiliki tekanan darah tinggi, obesitas sentral, dan dislipidemia, dengan atau tanpa hiperglikemik. Sindrom metabolik telah menjadi salah satu masalah kesehatan di masyarakat. Salah satu upaya untuk mencegahnya adalah dengan melakukan skrening secara dini. Kader dusun merupakan salah satu komponen masyarakat yang dapat menjadi agen untuk melakukan skrening tersebut. Sebagai kegiatan pengabdian pada masyarakat, maka pelatihan kader dusun dapat menjadi upaya pencegahan sindrom metabolik. Tujuan dari pelatihan adalah memberikan pengetahuan dan keterampilan kepada kader dusun untuk melakukan skrening sindrom metabolik di masyarakat. Pelatihan dilakukan dengan pemberian materi dan demonstrasi tentang cara melakukan skrening sindrom metabolik dan diikuti oleh 34 orang peserta. Hasil pelatihan menunjukkan bahwa terjadi peningkatan jumlah kader dusun yang memiliki pengetahuan dalam kategori baik sebesar $43,2 \%$. Berdasarkan hasil pengamatan yang dilakukan saat pendampingan, kader dusun yang dilatih dapat melakukan skrening sindrom metabolik seperti yang diharapkan. Kegiatan pelatihan dan pendampingan yang dilakukan cukup efektif untuk meningkatkan pengetahuan dan keterampilan kader dusun dalam melakukan skrening sindrom metabolik di Kabupaten Takalar.
\end{abstract}

Kata Kunci: kader dusun, metabolik, skrening, Takalar

\section{PENDAHULUAN}

Kabupaten Takalar adalah sebuah kabupaten di Provinsi Sulawesi Selatan, Indonesia. Ibu kotanya terletak di Pattallassang. Kab. Takalar terdiri dari sembilan kecamatan, yaitu Pattallassang, Polombangkeng Selatan, Polombangkeng Utara, Galesong, Galesong Selatan, Galesong Utara, Sanrobone, Mappakasunggu dan Manggarabombang. Kabupaten ini memiliki luas wilayah 
$566,51 \mathrm{~km}^{2}$ dan berpenduduk sebanyak \pm 250.000 jiwa. Keadaan Geografi wilayah Kabupaten Takalar terdiri dari pantai, daratan dan perbukitan. Di bagian barat adalah daerah pantai dan dataran rendah dengan kemiringan 0-3 derajat sedang ketinggian ruang bervariasi antara 0-25 $\mathrm{m}$, dengan batuan penyusun geomorfologi dataran didominasi endapan alluvial, endapan rawa pantai, batu gamping, terumbu dan tufa serta beberapa tempat batuan lelehan basal. Sebagian dari wilayah Kabupaten Takalar merupakan daerah pesisir pantai, yaitu sepanjang 74 $\mathrm{Km}$ meliputi Kecamatan Mangarabombang, Kecamatan Mappakasunggu, Kecamatan SandraBone, Kecamatan Galesong Selatan, Kecamatan Galesong Kota dan Kecamatan Galesong Utara. Kabupaten Takalar dilewati oleh 4 buah sungai,yaitu Sungai Jeneberang, Sungai Jenetallasa, Sungai Pamakkulu dan Sungai Jenemarrung. Pada keempat sungai tersebut telah dibuat bendungan untuk irigasi sawah seluas $13.183 \mathrm{Ha}$ (Syam, 2019)

Masalah kesehatan yang ada di Kabupaten Takalar adalah kecendrungan peningkatan kejadian penyakit tidak menular (PTM), seperti Diabetes dan hipertensi. Pada tahun 2014, prevalensi hipertensi di Kabupaten Takalar adalah $13,5 \%$. Sayangnya, jumlah kematian akibat PTM belum terlaporkan secara rutin (Dinas Kesehatan Kabupaten Takalar, 2014).

Sindroma Metabolik (SM) adalah kondisi dimana seseorang memiliki tekanan darah tinggi, obesitas sentral dan dislipidemia, dengan atau tanpa hiperglikemik. Data tentang prevalensi SM di Indonesia masih terbatas meski kecendrungan kejadiannya terus meningkat seiring dengan peningkatan kejadian obesitas. Seperti data dari Himpunan Studi Obesitas Indonesia (HISOBI) menunjukkan bahwa prevalensi SM adalah sebesar 13,3\% (Fattah, 2006). Penelitian di Jakarta menemukan bahwa dari 1591 responden yang diukur, dengan menggunakan definisi dari The Adult Treatment Panel Guidelines (ATP III) terdapat prevalensi SM sebesar $28,4 \%$, dimana terdapat prevalensi SM sebesar $25,4 \%$ pada pria dan $30,4 \%$ pada wanita. Komponen utama Sindrom metabolik yang ditemukan pada pria adalah hipertensi, sedangkan pada wanita adalah obesitas sentral (Soewondo dkk., 2010). Studi di Bali menemukan bahwa dari 109 sampel yang diperiksa ditemukan komponen SM seperti lingkar perut yang berisiko $(37,6 \%)$, kadar glukosa darah yang tinggi $(16,5 \%)$, total kolesterol yang tidak normal (37,0\%) dan hipertensi $(21,1 \%)$. Pada penelitian tersebut terdapat 27,5\% responden yang mengalami SM (Wiardani dkk., 2018). Di Makassar, sebuah studi yang melibatkan 330 pria menemukan prevalensi SM sebesar 33,9\% (Adrianjah dan Adam, 2006). Bahkan pada penelitian terakhir yang dilakukan pada guru sekolah menengah di kota ini ditemukan prevalensi SM meningkat menjadi 39,5\% (Hasan dkk., 2019)

Salah satu upaya untuk mencegah terjadinya PTM dan memperbaiki sistem pelaporan kejadian dan kematian karena penyakit tersebut, maka Dinas Kesehatan kabupaten Takalar telah membentuk kader dusun di tahun 2018. Terbentuknya kader dusun karena dibutuhkannya agenagen kesehatan atau pemberi informasi kesehatan kepada masyarakat hingga tingkat dusun, sehingga semua informasi dan masalah kesehatan dapat segera diketahui oleh petugas kesehatan, dan selanjutnya dapat dilakukan intervensi. 
Selain itu juga, adanya kader dusun ini dibutuhkan untuk membantu pelayanan kesehatan dalam melakukan skrining dan pemeriksaan kesehatan kepada seluruh masyarakat. Perbedaan strategi penyelesaian permasalahan (solusi) melalui kegiatan pemberdayaan masyarakat agar kegiatan ini dapat berlangsung secara berkelanjutan adalah dengan melakukan pelatihan kader dusun secara efektif.

Kader dusun sendiri sepertinya baru pertama kali ada di Sulawesi Selatan karena berdasarkan berbagai pencarian belum ditemukan adanya kader dusun di tempat lain. Kader yang biasa dijumpai adalah kader desa, kader PKK ataupun kader remaja. Sehingga pelatihan kader dusun ini adalah pelatihan yang baru pertama kali dilakukan di Sulawesi Selatan. Tujuan kegiatan pengabdian kepada masyarakat ini adalah untuk meningkatkan pengetahuan dan keterampilan kader dusun dalam melakukan skrening SM di masyarakat di Desa Pa'lalakang Kecamatan Galesong Kabupaten Takalar.

\section{METODE KEGIATAN}

Kegiatan pengabdian pada masyarakat ini terdiri dari kegiatan pelatihan dan pendampingan kader dusun. Pelatihan kader dusun dilaksanakan di Aula Kantor Desa Pa'lalakang pada Hari Sabtu tanggal 29 Juni 2019, sedangkan kegiatan pendampingan dilakukan selama 6 hari, yaitu Hari Senin-Sabtu tanggal 1-6 Juli 2019. Khalayak Sasaran pada pelatihan ini adalah kader dusun yang telah terbentuk sebelumnya juga ditambah kader baru yang mendaftar. Terdapat 60 orang warga yang mendaftar sebagai kader dusun, namun hanya 34 orang yang menghadiri kegiatan pelatihan.

Kader dusun ini berasal dari masyarakat Desa Pa'lalakkang. Kabupaten Takalar memiliki prevalensi penyakit degeneratif yang cukup tinggi, karena itu maka pemerintah berusaha mengatasi maslaha dengan membentuk kader dusun. Salah satu desa yang telah membentuk kader dusun adalah desa Pa'lalakang. Sayangnya kader dusun ini belum dibekali dengan pengetahuan dan keterampilan melakukan pencegahan penyakit degeneratif di masyarakat. Karena itu tim pengabdi tertarik untuk membantu memberikan pelatihan dan pendampingan kepada kader dusun untuk melakukan skrening terhadap SM.

Kegiatan pengabdian ini bermitra dengan Desa Pa'lalakang. Sebelum dilakukan kegiatan pelatihan, tim pengabdi melakukan pendataan terhadap kader dusun yang ada. Ternyata jumlah kader belum memadai sesuai dengan jumlah penduduk. Karena itu, tim pengabdi membuka pendaftaran bagi kader baru yang ingin bergabung sebagai kader dusun. Setelah itu tim pengabdi mempersiapkan kegiatan pelatihan dengan menyusun modul dan materi tayang.

Sebelum diberikan pelatihan, khalayak sasaran diberikan kuesioner pre tes untuk mengetahui pengetahuan kader sebelum pelatihan. Pengetahuan tersebut diukur kembali dengan kuesioner posttest setelah pelatihan dilaksanakan. Pengetahuan yang diukur pada saat pre dan post test meliputi faktor risiko SM, nilai batas serta gejala dari komponen SM, dan cara mencegah terjadimya SM. Untuk memantapkan pengetahuan peserta, tim pengabdi juga melakukan demonstrasi pengukuran antropometri dan 
pengukuran tekanan darah dengan alat ukur digital. Setelah itu, kader dusun diberikan pendampingan selama 6 hari. Dimana para kader dusun akan mencari orang yang berisiko tinggi terhadap SM, lalu kader dusun akan mengukur antropometri serta tekanan darah orang tersebut. Untuk menilai apakah orang tersebut mengalami SM atau tidak.

Kader dusun juga memberikan edukasi tentang gaya hidup sehat untuk mencegah penyakit degeneratif kepada orang tersebut. Kegiatan ini dikatakan berhasil apabila terdapat peningkatan pengetahuan kader dusun dalam kategori baik sebesar $40 \%$ pada saat sebelum dan setelah pelatihan. Angka $40 \%$ tersebut diperoleh berdasarkan hasil kegiatan pengabdian yang pernah dilakukan sebelumnya, dimana pelatihan edukator sebaya yang dilakukan tim pengabdi hanya berhasil meningkatkan pengetahuan peserta pada kategori baik sebesar $43 \%$ saja (Jafar, 2018). Sehingga tim pengabdi menetapkan bahwa pelatihan tentang SM dikatakan efektif jika berhasil memperbaiki pengetahuan khalayak sasaran sebesar $40 \%$.

\section{HASIL DAN PEMBAHASAN}

\section{Pelatihan Kader Dusun}

Sebelum dilaksanakan pelatihan kader dusun, tim pelaksana kegiatan pengabdian kepada masyarakat melakukan serangkaian persiapan, seperti upaya untuk menjaring kader calon peserta pelatihan, mengurus perizinan serta menyusun materi pelatihan. Pelatihan kader dusun sendiri dilakukan di aula Desa Pa'lalakang pada tanggal 29 Juni 2019

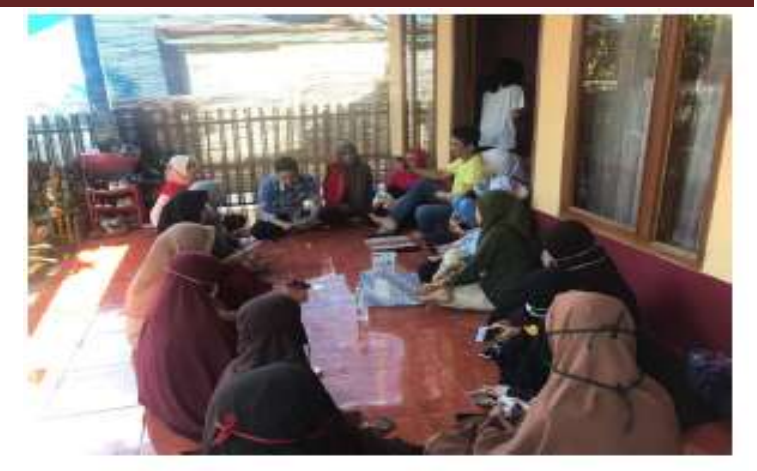

Gambar 1. Persiapan pelaksanaan pelatihan kader dusun

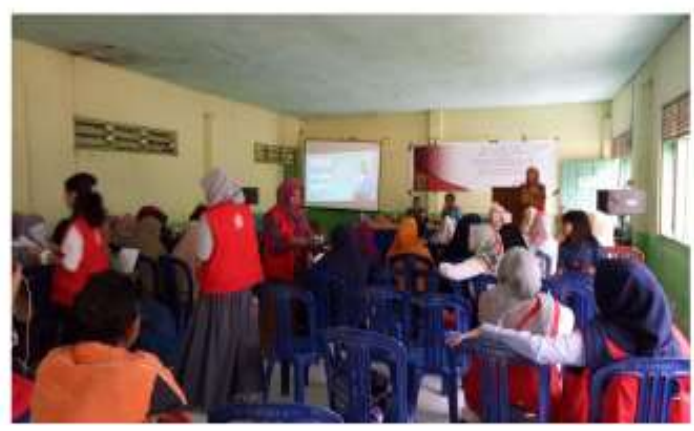

Gambar 2. Pelaksanaan pelatihan kader dusun

Materi yang diberikan pada pelatihan ini adalah tentang SM dan cara untuk melakukan skrening SM di Masyarakat. Peserta pelatihan ini adalah sebanyak 37 orang. Berdasarkan hasil kuesioner, ditemukan bahwa sebelum pelatihan terdapat $18,9 \%$ responden yang memiliki pengetahuan baik. Setelah pelatihan, pengetahuan responden dalam skala baik meningkat sebesar $43,2 \%$ menjadi $62,1 \%$. Untuk pengetahuan cukup, sebelum pelatihan ditemukan terdapat $45,9 \%$. Dan setelah pelatihan, menurun sebesar $13,5 \%$ menjadi $32,4 \%$. Untuk pengetahuan kurang, sebelum pelatihan terdapat $35,2 \%$. Setelah pelatihan mengalami penurunan sebesar $29,7 \%$ menjadi $5,4 \%$ 
Tabel 1. Pengetahuan responden tentang SM sebelum dan setelah pelatihan

\begin{tabular}{lccccl}
\hline \multirow{2}{*}{ Pengetahuan } & \multicolumn{2}{c}{$\begin{array}{c}\text { Sebelum } \\
\text { Pelatihan }\end{array}$} & \multicolumn{2}{c}{ Setelah Pelatihan } & Perubahan \\
& $\mathrm{n}$ & $\%$ & $\mathrm{~N}$ & $\%$ & \\
\hline Baik & 7 & 18,9 & 23 & 62,1 & Meningkat 43,2\% \\
Cukup & 17 & 45,9 & 12 & 32,4 & Menurun 13,5\% \\
Kurang & 13 & 35,2 & 2 & 5,4 & Menurun 29,7\% \\
\hline
\end{tabular}

Kuesioner terdiri dari 20 pertanyaan yang mencakup aspek pengetahuan tentang faktor risiko SM, nilai batas serta gejala dari komponen SM, dan cara mencegah terjadimya SM. Jawaban pertanyaan yang benar diberi nilai 5, sedangkan bila jawaban salah tidak mendapatkan nilai, sehingga nilai maksimal yang dapat diperoleh responden adalah 100 dan nilai minimal adalah 0 . Pengetahuan responden dikategorikan baik jika nilainya $\geq 80$, cukup jika nilainya 60-80, dan kurang jika nilainya $<60$.

Perubahan pengetahuan responden pada sebelum dan setelah pelatihan dapat dilihat pada grafik berikut :

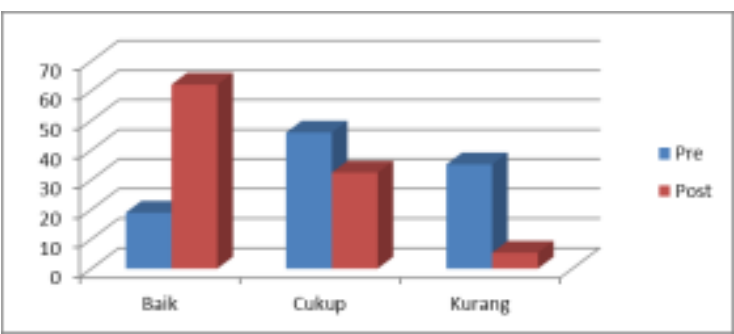

Gambar 3. Perubahan pengetahuan kader dusun sebelum dan setelah pelatihan

Berdasarkan hasil pengabdian yang dilakukan, terlihat bahwa kegiatan pelatihan kader dusun cukup efektif untuk memperbaiki pengetahuan khalayak sasaran. Terlihat bahwa pelatihan yang dilakukan meningkatkan pengetahuan dalam kategori baik serta menurunkan pengetahuan dalam kategori cukup dan kurang. Hasil ini serupa dengan hasil yang telah diperoleh kegiatan pengabdian lain yang terlebih dahulu dilakukan. Seperti IBM pelatihan dan pendampingan kader posyandu lanisa di Dusun Mudal Sariharjo, setelah pelatihan dilakukan terdapat peningkatan pengetahuan kader tentang faktor risiko penyakit tidak menular. Setelah kader tersebut melakukan konseling kepada lansia, ditemukan bahwa pengetahuan lansia yang mendapat konseling juga turut meningkat (Utami dan Endriyani, 2017).

Studi lain menemukan bahwa setelah pelatihan tentang pemeriksaan fisik, seluruh kader yang dilatih mampu melakukan pengukuran pernapasan, nadi dan tekanan darah serta $70 \%$ kader dapat mengukur tekanan darah dengan menggunakan tensi meter air raksa dan pegas (Amigo dan Muflih, 2017). Studi di Bantul menemukan bahwa rata-rata kemampuan kader dalam pengelolaan posyandu adalah 5,28 (kurang baik), namun setelah diberi pelatihan pengelolaan kader meningkat menjadi 8,29 (baik).

Pelatihan yang dilakukan efektif dalam memperbaiki kemampuan kader untuk melakukan pengelolaan posyandu (Suryani dan Isnaeni, 2013). Tidak hanya di bidang kesehatan, pelatihan juga dilakukan ada bidang lain, seperti budidaya perikanan. Seperti pelatihan penanganan streptococcusis pada ikan nila. Pelatihan yang dilakukan dapat 
meningkatkan wawasan dan informasi bagi para pembudidaya selama masa pemeliharaan ikan dan meningkatkan kemampuan masyarakat dalam pembuatan pakan ikan (Azhar dan Wirasisya, 2019).

\section{Pendampingan Kader Dusun oleh Mahasiswa}

Setelah dilakukan pelatihan, kader dusun kemudian didampingi oleh mahasiswa untuk melakukan skrening SM di masyarakat. Skrening dilakukan dengan melihat faktor risiko kemudian dilanjutkan dengan pengukuran antropometri. Pengukuran antropometri yang dilakukan terdiri dari penimbangan berat badan dan pengukuran tinggi badan, lingkar perut dan tekanan darah. Berdasarkan hasil observasi yang dilakukan, terlihat bahwa kader dusun telah mampu melakukan skrening SM di Masyarakat sesuai dengan hasil pelatihan yang telah didapatkan.

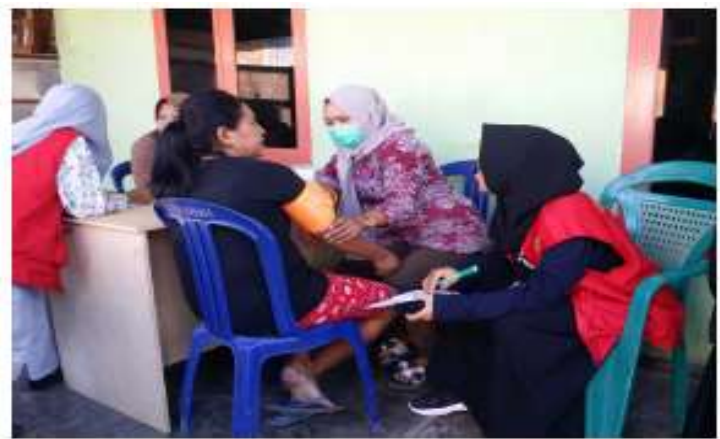

Gambar 3. Pendampingan saat kader mengukur tekanan darah

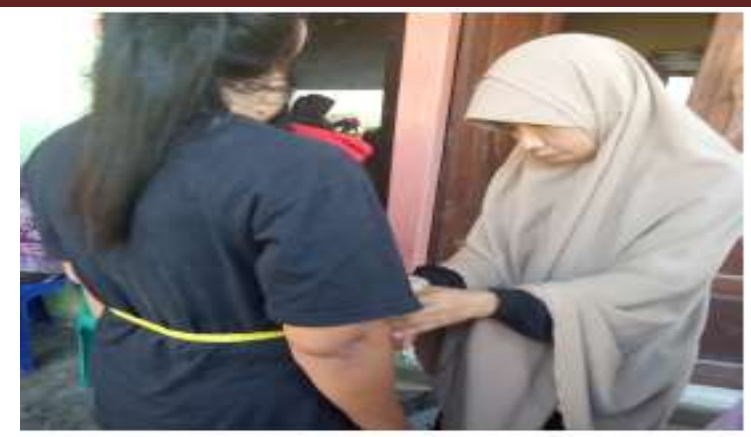

Gambar 4. Pendampingan saat kader mengukur lingkar perut

Pada kegiatan pendampingan, setelah dilakukan observasi terlihat bahwa kader yang dilatih cukup terampil dalam melakukan skrening SM. Para kader tersebut dapat melakukan pengukuran antropometri maupun tekanan darah. Kegiatan pendampingan memang sering digunakan untuk mencapai perbaikan tertentu. Baik pada bidang kesehatan maupun bidang lain, misalnya pariwisata. Pada bidang kesehatan, kegiatan pendampingan kader kesehatan dalam strategi produksi dan promosi MP-ASI mampu meningkatkan pengetahuan dan minat kader kesehatan dalam produksi dan pemasaran MP ASI yang sehat (Purwati dkk., 2018).

Demikian pula pada pendampingan kader pendidikan anak usia dini (PAUD). Kegiatan pemberdayaan masyarakat dan keluarga dalam pendidikan anak usia dini melalui pendampingan kader PAUD mampu menjadi percontohan bagi terbentuknya kelompok PAUD di dukuh lain. Sehingga pada akhir kegiatan telah terbentuk PAUD pada semua dukuh (Abdullah dkk., 2019). Pada bidang pariwisata, pendampingan aplikasi buku bahasa Inggris praktis bagi pedagang souvenir di pasar seni Taman Narmada membuat masyarakat dapat mengetahui, mempraktekkan pengalaman selama pendampingan berlangsung dalam 
memperkenalkan souvenir, mengatakan harga dan transaksi, menunjukkan dan menjelaskan tempat-tempat yang menarik di Taman Narmada (Arafiq dkk., 2019)

\section{KESIMPULAN DAN SARAN}

\section{Kesimpulan}

Pelatihan dan Pendampingan yang dilakukan efektif untuk meningkatkan pengetahuan dan keterampilan kader dusun dalam melakukan skrening SM di Desa Pa'lalakkang, Kecamatan Galesong, Kabupaten Takalar.

\section{Saran}

Kegiatan ini diharapkan dapat menjadi program kerja yang diteruskan oleh institusi terkait, seperti Puskesmas sebagai bentuk pemberdayaan masyarakat dalam pencegahan penyakit degeneratif

\section{UCAPAN TERIMA KASIH}

Penulis mengucapkan terima kasih kepada Bupati Takalar, Camat Galesong dan Kepala Desa Pa'lalakkang atas kerjasama yang diberikan. Penulis juga mengucapkan terima kasih kepada peserta KKN-PPM Dikti tahun 2019 serta kepada kader dusun dan masyarakat Pa'lalakkang. Terakhir, penulis mengucapkan terima kasih kepada Kemenristedikti untuk bantuan dana yang diberikan bagi pelaksanaan kegiatan melalui Hibah KKN-PPM Dikti Tahun 2019.

\section{DAFTAR PUSTAKA}

Abdullah, S.M, Widyana, R, Astuti, K., 2019. Pemberdayaan Masyarakat dan Keluarga dalam Pendidikan Anak Usia Dini melalui Pendampingan Kader PAUD di Desa Sumbersari,
Moyudan, Sleman, Yogyakarta. Jurnal Sosiohumaniora, 1 (2) 96108,:http://ejurnal.mercubuanayogya.ac.id/index.php/soshum/articl e/view/81

Adrianjah, H, Adam, J., 2006. Sindrom Metabolik : Pengertian, Epidemiologi dan Kriteria Diagnosis. Jakarta: Informasi Laboratorium PRODIA.

Amigo, T.A.E dan Muflih, 2017. Pelatihan Kader Pemeriksaan Fisik : Tandatanda vital di Dusun Demangan dan Karangsari, Wedomartani, Sleman, Yogyakarta. Medika Respati. http://medika.respati.ac.id/index.ph $\mathrm{p} /$ Medika/article/view/67

Arafiq, Hanafi, N., Husni, M., Syahdan, Yusra, K., 2019. Pendampingan Aplikasi Buku Bahasa Inggris Praktis Bagi Pedagang Souvenir di Pasar Seni Taman Narmada. Abdi Insani, 6 (1) : 72-79,:

http://abdiinsani.unram.ac.id/index. php/jurnal/article/view/187

Azhar, F. dan Wirasisya, D.G. 2019. Pelatihan Penanganan Streptococusis pada Ikan Nila (Oreochromus Nilotikus) Menggunakan Pakan Fermentasi di Desa Gontoran Lingsan. Abdi Insani, 6(2): 229-240,: http://abdiinsani.unram.ac.id/index. php/jurnal/article/view/240

Dinas Kesehatan Kabupaten Takalar. 2014. Profil Kesehatan Kabupaten Takalar. Takalar:Dinas Kesehatan Kabupaten Takalar.

Fattah, M. 2006. Sindroma Metabolik dan Penanda Baru Disfungs Endotel: Asimetrik Dimetrik Arginin (HDMA) dan High Sensitive C-Reaktif Protein (Hs-CRP). Forum Diagnosticum , (1).

Hasan, N,. Hadju, V, Jafar, N., Thaha, R. 2019. Prevalence of Metabolic 
Syndrome (Mets) and Determinants Among Obese Teacher in Makassar, Indonesia. International Medical Journal Malaysia, 18 (2) : 29-34,: https://journals.iium.edu.my/kom/in dex.php/imim/article/view/100

Jafar, N., Syam, A., Indriasari, R., Arundhana, IA. 2018. Laporan Akhir Kegiatan Pengabdian "Pelatihan Edukator Sebaya Sebagai Upaya Pencegahan Komponen Sindrom Metabolik pada Remaja di Kabuapaten Soppeng. LPPM Universitas Hasanuddin. Makassar

Purwati, Y., Salmiyati, S. dan Imallah, R.N. 2018. Pendampingan Kader Kesehatan dalam Strategi Produksi dan Promosi MP ASI. Abdimas Dewantara, 1(2): 96-108,: http://jurnal.ustjogja.ac.id/index.ph $\mathrm{p} / \mathrm{abdimasdewantara/article/view/3}$ $\underline{057}$

Soewondo, P., Purnamasari, D., Oemardi, M., Waspadji, M., Soegondo, S. 2010. Prevalence of Metabolic Syndrome Using NCEP/ATP III Criteria in Jakarta Primary NonCommunicable Disease Risk Factors Surveilance 2006. Acta Med Indonesia, 42(4):199-203,: https://www.ncbi.nlm.nih.gov/pubm ed/21063040
Suryani, E. D. dan Isnaeni. 2013. Pengaruh Pelatihan Kader Terhadap Kemampuan Melakukan Pengelolaan Posyandu di Desa Srihandonu, Pundong, Bantul, Yogyakarta. Yogyakarta: Skripsi Universitas Aisyiyah

http://digilib.unisayogya.ac.id/594/1 /NASKAH\%2OPUBLIKASI\%20EVA\%20 DWI\%20SURYANI.pdf.pdf

Syam, A., Jafar, N., Virani, D. 2019. Pelatihan Kader Dusun Sebagai Upaya Pencegahan Komponen Sindrom Metabolik di Kabupaten Takalar. Laporan KKN-PPM. LPPM Universitas Hasanuddin, Makassar

Utami, I dan Endriyani, A. 2017. IBM Pelatihan dan Pendampingan Kader Posyandu Lansia di Dusun Mudal Sariharjo Ngaglik Sleman, 2017. Prosiding Seminar Nasional dan Internasional LPPM Unismuh Semarang.

https://jurnal.unimus.ac.id/index.ph p/psn12012010/article/view/2919

Wiardani, N.K., Kusumajaya, Arsana. 2018. Macronutrient Intake and Metabolic Syndrome Status Toward Tour Guide, 2(1): 29-43. International Journal of Health Science, https://sciencescholar.us/journal/in dex.php/ijhs/article/view/97. 